\section{Causal agents of Post-harvest Rot of Pumpkin (Cucurbita pepo L.) and their control using Indigenous Practices in Hong, Adamawa State}

\author{
Kazi N, Chimbekujwo IB and Anjili SM* \\ Department of Plant Science, School of Life Sciences, Moddibo Adama University of Technology, \\ Yola, Adamawa State, Nigeria
}

\section{Abstract}

Pumpkins (Cucurbita pepo) are grown all around the world for a variety of reasons ranging from agricultural purposes to commercial and ornamental sales. The pathogens causing the rot of pumpkin in the world include fungi, bacteria, and viruses. The study was aim to identify fungal pathogens of pumpkin rot during storage, as well as control measures of the diseases using wood ash, mango leaf and rice chaff. Three hundred and sixty-six (366) fruits of pumpkins were studied in Pela, Gaya and Kulinyi districts of Hong Local Government Area of Adamawa State. The diseased samples (fruits) were randomly purchased. Of all the districts visited, Kulinyi has the highest percentage of disease samples (43.82\%) while the least is Gaya district with 21.35\%. Potato Dextrose Agar (PDA) was used for the isolation of pathogens and these gave Rhizopus stolonifer, Aspergillus niger, Aspergillus flavus, and Phytophthora capsici. All the fungal isolates exhibited different degree of pathogenic effect on the pumpkin fruits. The pathogens are susceptible to treatment both In-vitro and In-vivo control trials with wood ash and mango leaf at $p \leq 0.05$. Inhibition improved with increased in concentration of the wood ash and mango leaf. Rice chaff treatment equally proved worthwhile with significant inhibition compared to the control at $\mathrm{p} \leq 0.05$.

\section{More Information}

*Address for Correspondence: Anjili SM, Department of Plant Science, School of Life Sciences, Moddibo Adama University of Technology, Yola, Adamawa State, Nigeria, Email:mrsee003@gmail.com

\section{Submitted: 01 July 2019 \\ Approved: 18 July 2019 \\ Published: 19 July 2019}

How to cite this article: Kazi N, Chimbekujwo IB Anjili SM. Causal agents of Post-harvest Rot of Pumpkin (Cucurbita pepo L.) and their control using Indigenous Practices in Hong, Adamawa State. J Plant Sci Phytopathol. 2019; 3: 062-066.

DOI: 10.29328/journal.jpsp.1001033

Copyright: @ 2019 Kazi N, et al. This is an open access article distributed under the Creative Commons Attribution License, which permits unrestricted use, distribution, and reproduction in any medium, provided the original work is properly cited

Keywords: Pumpkin fruit pathogens; Ash; Mango leaf; Rice chaff

\section{Check for updates}

\section{Introduction}

Pumpkin, one of the common names for flowering plants that belong to the Curcubitaceae family with four genera which include Curcubita maxima, Curcubita pepo, Curcubita moschata and Cucurbita mixta. They are characterized by spreading vines with showy yellow-orange flowers, large lobed leaves, long twisting tendrils and thick shell which contain the seeds and pulp [1]. They are grown all around the world for a variety of reasons ranging from agricultural purposes (such as animal feed) to commercial and ornamental purposes [2].

In Nigeria, it is a traditional vegetable crop, grown mainly for its leaves, fruits, and seeds and, consumed either by boiling the leaves and fruits or by baking the seed [3]. In Hong local government of Adamawa state, there was a huge production of pumpkins, but the crops suffer from many diseases which destroy both the crops and fruits during harvest and storage resulting to economy loss.

Postharvest diseases destroy $10-30 \%$ of the total yield of crops and in some perishable crops especially in developing countries; they destroy more than $30 \%$ of the crop yield $[4,5]$. The marketability and the nutritional value of infected pumpkin are highly reduced and they are usually being thrown away as useless [6]. Fungi are the most important and prevalent pathogens, infecting a wide range of host plants and causing destructive and economically important losses of most fresh fruits and vegetables during storage and transportation [7]. Crop losses due to the soil borne fungus like oomycete Phytophthora capsici (Leonian) have been well documented $[8,9]$. Phytophthora capsici affects a wide range of solanaceous and cucurbit hosts worldwide [9]. Fusarium crown and foot rot of squash and pumpkin is caused by Fusarium solani f. sp. cucurbitae. The pathogen exhibits host specificity for all cucurbits [10]. Bacterial wilt can be a serious disease in pumpkin plantings if striped or spotted cucumber beetles are present when plants first emerge from the soil. Mosaic viruses can cause problems on pumpkin plantings in the home garden.

Pumpkin disease management begins with cultural and 
preventative controls such as proper site selection, field preparation and the use of resistant varieties, and by remembering that excess water is the enemy of your pumpkin planting. Ijato, [11] reported that plant parts, powder of plant, ash, aqueous extracts which are environmentally non-hazardous, locally available and can be cheaply maintained are suitable alternatives to the expensive synthetic fungicide. Bristone, et al. [12] reported that when tubers of sweet potatoes were treated with wood ash, rot caused by Rhizopus stolonifer and Penicillium expansum was reduced to minimal level. Extract of many higher plants have been reported to exhibit antibacterial, antifungal and insecticidal properties under laboratory trails Bonaldo, et al. Rodrigues, et al. [13,14]. Aisha, et al. [15] reported the use of guinea corn chaff on Solenoslemon rotundifolius [17]. Muhammed, et al. [16], observed that rice product like rice husks composted soil reduced the incidence of wilting of Parkia biglobosa caused by Fusarium solani in the range of $31.4 \%$ to $70.3 \%$. This study will be useful in providing knowledge on the fungal pathogens of pumpkin diseases during storage, as well as on control measures of pumpkin diseases using wood ash, mango leaf and rice chaff, thereby helping in reducing losses of the crops during storage.

\section{Materials and Methods}

\section{Study areas and samples collection}

The study of pathogens associated with pumpkins fruit was conducted in three districts (Kulinyi, Gaya and Pella) in Hong local government of Adamawa state. In each district, 122 fruits were inspected and collected from market for further studies. The experimental design was Complete Randomized Design (CRD) arranged in three replicates.

\section{Survey of rot pumpkin}

Pumpkin that had been harvested from three out of the six districts of Hong local government which has been stored for commercial purposes were observed and every fruit with a rot was recorded. The incidence of fruit spoilage/rot was expressed in percentage using the adopted method of Anjili, et al. [17], Plants to

$\frac{\text { Number of pumpkin fruits with rot }}{\text { Total number of pumpkin fruits }} \times 100$

\section{Isolation and identification of isolates}

The isolation and identification from diseased pumpkin fruit was carried out using the methods of Fawole and Oso, [18] and Robert, et al. [19]. Under aseptic conditions the disease sample from spoilt pumpkin fruit was cut into approximately $2 \mathrm{~cm}$ with a neat sterile scalpel. The portion was immersed into $1 \%$ sodium hypochlorite contain for surface sterilization for 30 seconds. The sterilize portion was rinsed in three changes of sterile distilled water and then air dried between sterile filter papers. It was then plated out on steile solidified Potatoes Dextrose Agar (PDA) and incubated at room temperature of $31 \pm 2{ }^{\circ} \mathrm{C}$.

\section{Determination of severity during the pathogenicity analysis}

The pathogenecity test was carried using the method of Chukwuka, et al. [20], and the severity of rot was measured and recorded after seven days of incubation. Fifteen healthy pumpkins fruit were randomly selected and surfaced sterilized, then rinsed in three (3) changes of sterile distilled water. A sterile cork borer with $5 \mathrm{~mm}$ diameter was used to puncture pumpkin fruits and spores of the isolated fungi were inoculated into the fruit using sterile needle. A control set up was set with sterile distilled water to replace the fungal inocula. Then it was incubated for 7 days after which each fruit was collected and the extent of rot (severity of infection) was measured and recorded. The pathogens were re-isolated from the new host to show whether they are same with the originally inoculated pathogen.

\section{In-vitro effect of mango leaf extracts and ash on fungi Growth}

The approach of Ijato, [11] and Nene and Thapilyal, [21] were used to evaluate the effects of the extract on fungal growth In-vitro by introducing $0.5,1.0,1.5 \mathrm{ml}$ of plant extract into the Petri-dish containing equal amount of PDA media (food poisoned method) and swirled to mix. Each plate was inoculated with $2 \mathrm{~mm}$ diameter plug of the isolate and incubated at $31 \pm 2{ }^{\circ} \mathrm{C}$ and the control plates contained only the PDA media. Mycelia growth diameter of each isolates was measured and recorded when the growths of the isolates were completed in the control treatment. Similarly, different grams of sterilize ash were tested $(0 \mathrm{~g}$ for control, $5 \mathrm{~g}, 10 \mathrm{~g}$ and $40 \mathrm{~g})$. The set up was completely randomised design in three replicates, incubated at $31 \pm 2{ }^{\circ} \mathrm{C}$ for 7 days. The data recorded was analysed using SAS version 7 .

\section{In-vivo effect of mango leaf extracts, ash and rice chaff on fungi growth}

The methods of Bristone, [22] and Anjili, et al. [23] were used for In-vivo control trail by inoculating the fruits with spores' suspension of the isolated pathogens then $20 \mathrm{~g}, 30 \mathrm{~g}$ and $40 \mathrm{~g}$ of ash, mango leaf respectively were sprinkled separately on the bore samples in three replicates. A control was set with ash free. It was incubated at $31 \pm 2{ }^{\circ} \mathrm{C}$ for 7 days.

Similarly, healthy pumpkins were sterilized, punctured with sterilized $5 \mathrm{~mm}$ diameter cork-borer and inoculated with the isolated fungi. It was placed in-between rice chaff, and the control set up was without rice chaff. The set up was replicated thrice (3). It was kept for seven (7) days and after which the level of rot was measured with thread and ruler. The data recorded was analysed using SAS version 7.

Data collected were analysed using statistical tool 'Statisti- 
cal Analysis System (SAS)' for analysis of variance (ANOVA) and the means were separated using the least significant difference (LSD) at $95 \%$ probability level $(\mathrm{P} \leq 0.05)$.

\section{Result and Discussion}

Pumpkin fruits were observed to show different types of rot symptoms. A total number of 366 harvested pumpkin fruit were inspected in the three districts from the studied area, 89 diseased pumpkins were recorded during the survey (Table 1). Kulinyi district had the highest disease fruits with 39 , followed by Pella district with 31 and Gaya district had the least with 19. The major infection was black rot and water-soaked lesions. They were well spread and extensively prevalent in all the three districts of the studied area. Tsado, et al. [24] also reported fruit rots of pumpkin in markets and farms in Minna, Niger State of Nigeria. The highest incidence of disease fruit was however, more prominent in Kulinyi areas than in the other areas. This may not be unconnected with the number of farming activities. Tsado, et al. [24] also suggested that the presence of many pathogens in soils may be major sources of microorganisms present on many vegetables. Mapanda et al. [25] also shared the same view that pathogens existing in soils or water can be the source of both pre- and post-harvest contamination of several vegetables. Amadioha and Obi, [26] have shown how most of the vegetables consumed are not produced by highly knowledgeable people therefore, liable to be unsafe for consumption.

The isolated fungi from the pumpkin fruit in Hong Adamawa State were identified as Rhizopus stolonifer, Aspergillus niger, Aspergillus flavus, Phytophthora capsici.

Rhizopus stolonifer was the most prevalent in Kulinyi compared to the other districts, while Phytophthora capsici was the lowest isolated pathogen and it was observed only in Pella district (Table 2).

All the fungal isolates exhibited different degree of pathogenic effect on the pumpkin fruits. They were able not only to grow on the fruits but also were able to induce

Table 1: Percentage of Disease Fruits (Pumpkin) from the Selected Districts of the Area of Study.

\begin{tabular}{|c|c|c|}
\hline Districts & Number of diseased fruits & \% diseased fruits \\
\hline Gaya & 19 & 21.35 \\
\hline Kulinyi & 39 & 43.82 \\
\hline Pella & 31 & 34.83 \\
\hline Total & 89 & 27.48 \\
\hline
\end{tabular}

Table 2: Percent Incidence of Postharvest Fungi of Pumpkin fruits from three districts.

\begin{tabular}{|c|c|c|c|}
\hline \multicolumn{4}{|c|}{ Districts } \\
\hline Fungi & Gaya (\%) & Kulinyi (\%) & Pella (\%) \\
\hline Rhizopus stolonifer & 45.00 & 50.00 & 35.00 \\
\hline Aspergillus niger & 25.00 & 30.00 & 30.00 \\
\hline Aspergillus flavus & 30.00 & 20.00 & 25.00 \\
\hline Phytophthora capsici & 0.00 & 0.00 & 5.00 \\
\hline
\end{tabular}

some level of rot indicating their virulence. However, there is no growth evident or rot formation within the first 24 hours after inoculation in all cases. Rots caused by this fungus occurred on all pumpkin fruits. The lesions started as water-soaked, sometimes sunken, and light to dark spots which often exuded watery ooze. Older lesions were dried and cracked, and fruiting bodies of the fungus were common seen on the surface and deep when it was cut. The rots were characterized by a water-soaked appearance and infected fruit often collapsed completely in the time between inspections. Internally, the tissue was spongy and sometimes dried out, with the mycelium of the fungus clearly visible. The analysis of variance to determine the level of severity at $p<0.05$ showed to be highly significant among all the pathogens with control. Rhizopus stolonifer had the highest severity mean of $121.67 \mathrm{~mm}$, followed by Aspergillus niger with $19.85 \mathrm{~mm}$, Aspergillus flavus $(8.71 \mathrm{~mm})$, while Phytothora capsici had the least mean of $2.71 \mathrm{~mm}$ (Table 3). Zakari, et al. [27] reported similar observation on the degree of pathogenicity though on pepper fruits a different vegetable where he also found Aspergillus species more virulence than Phytophthora capsici. The differences in severity of the fungi isolated might be due to their ability to overcome the natural defense mechanism of the fruit or their ability to induce resistance in the fruit when infected [28]. On the Phytophthora rot, Babadoost, [29] further maintained that Phytophthora capsici can infect pumpkin fruit at any stage of development (during transit, and in storage). Hausbeck, et al. [30] also reported P. capsici has been found to associate with postharvest rot of some vegetables viz., taro (Colocasia esculenta (L.) Schott), bottle gourd (Lagenaria siceraria (Molina) Standley), eggplant (Solanum melongena L.), common bean (Phaseolus vulgaris L.), sponge gourd (Luffa aegyptiaca Mill.) and tomato (Lycopersicon esculentum Mill.).

The phytochemical characteristics of mango leaves investigated revealed the presence of medicinally active constituents and secondary metabolites, these includes tannins, flavanoids, saponins, terpenoids, alkaloid, glycoside, steroids and phenols (Table 4) and the phytoconstituents in the leaf extracts may be responsible for the antifungal [31] and antibacterial activity of the plant [32].

The effects of mango leaves, ash and rice chaff on isolated organism

Mango leave extracts both in-vivo and in-vitro produced a significant difference between the mango leave extract and the control at $p \leq 0.05$ with retardation of vegetative growth of the fungi when compared with the control. Treatment with mango

\begin{tabular}{|c|c|c|}
\hline \multicolumn{2}{|c|}{ Table 3: Severity Mean of the Organisms on the fruits. } \\
\hline Source & Lesion size $(\mathbf{m m})$ & Control $(\mathbf{m m})$ \\
\hline R. stolonifer & 121.67 & 0 \\
\hline A. niger & 19.85 & 0 \\
\hline A. flavus & 8.71 & 0 \\
\hline P. capsici & 2.71 & 0 \\
\hline
\end{tabular}


Table 4: Qualitative and Quantitative Determination of Phytochemical Properties of the Mango Leave Extracts.

\begin{tabular}{|c|c|c|}
\hline Phytochemicals & Mango leaf & Mango leaf in \% \\
\hline Tannin & + & 11.3 \\
\hline Saponin & + & 7.8 \\
\hline Terpenoid & + & 4.6 \\
\hline Flavonoid & + & 16.9 \\
\hline Alkaloid & + & 7.1 \\
\hline Glycoside & + & 21.7 \\
\hline Steroid & + & 3.1 \\
\hline Phenols & + & 18.3 \\
\hline Anthraflanols & - & - \\
\hline Protein & - & - \\
\hline Carbohydrate & - & - \\
\hline
\end{tabular}

leaf extract on organisms differs significantly with the quantity of the extracts applied and among the isolates treated. It has been documented that different solvents and quantities have diverse solubility capacities for different phytoconstituents. Jigna and Sumitra [33], report the difference in activities may be associated with the presence of oils, wax, resins, fatty acids or pigments, which had been reported capable of blocking the active ingredients in the plant extracts, thus, preventing the plant extract from accessing the fungal cell wall. of all the fungi tested the Phytophthora capsici was slightly more susceptible to the extracts than the Aspergillus species and Rhizopus stolonifer. The finding agreed with earlier reports that Phytopthora capsisi are more susceptible to extracts from Tridax procumbens, Vernonia amygdalina, and Azadirachta indica than other Aspergillus species among other fungi isolated from pepper in Yola [27] (Tables 5 and 7).

Ash treatment in both in-vitro and in-vivo produced a significant difference between ash treatment and the control at $\mathrm{p} \leq 0.05$. Treatment also differs significantly with the quantity of the ash applied and this was also reported by Anjili, et al. [23] and [34] who worked on fungi isolated from date palm fruits and cowpea blotch respectively. Channya and Chimbekujwo [35], reported that wood ash effectively controlled fungal rot of plantains (Musa parasidiaca L.). Bristone, et al. [12] reported that when tubers of sweet potatoes were treated with wood ash, rot caused by Rhizopus stolonifer and Penicillium expansum was reduced to minimal level. Oguntade and Adekunle, [36], also reported that wood ashes proved effective in preserving stored crops against pest and microbes (Tables 6 and 8).

The control using rice chaff produced a significant difference between rice chaff and the control at $\mathrm{p} \leq 0.05$. Muhammed, et al. [16] in their studies observed that rice product like rice husks composted soil reduced the incidence of wilting of Parkia biglobosa caused by Fusarium solani. According to Aliyu, et al. [37] amending cowpea with rice husk showed considerable less susceptibility to the virus pathogen infecting cowpea compared to the non-amended plants. $\mathrm{He}$ further showed that the rate and time of application of the
Rice-husk powder was a key factor in the ameliorative effect of this organic amendment in the suppression of the viral inoculums. Muhammed, et a.l [38] reported a significant effect of guinea corn chaff on Solenoslemon rotundifolius microbes. These clearly show why fungi isolated from pumpkin responded differently with different amendment (Table 9).

\section{Conclusion}

Rhizopus stolonifer, Aspergillus niger, Aspergillus flavus, Phytophthora capsici are some of the pathogenic fungi which cause rots of pumpkin in the studied area. The pathogenicity test result indicated that the isolated fungi are pathogenic and attributed to rots of pumpkin in Hong L.G.A. The activities of these fungi can affect the market value of fruits. Of all the treatments, wood ash which is alkaline shows to be more promising than other treatments. Therefore, there is need to assess the phytochemical properties of the fruits in order to determine the level of nutritional loss as a result of the activities of pathogens.

Table 5: The Efficacy of different Concentration of Mango Leaf Extract on Isolated Organisms In-vivo

\begin{tabular}{|c|c|c|c|c|}
\hline Conc. $(\mathbf{m l})$ & R. stolonifer & A. niger & A. flavus & P. capsici \\
\hline 5 & 66.61 & 19.85 & 4.33 & 1.71 \\
\hline 10 & 22.29 & 8.50 & 4.05 & 0.62 \\
\hline 15 & 13.33 & 5.90 & 2.30 & 0.43 \\
\hline 0 & 121.67 & 34.80 & 8.71 & 2.71 \\
\hline LSD (0.05) & 20.62 & 9.12 & 1.21 & 0.70 \\
\hline
\end{tabular}

Table 6: The Efficacy of Wood Ash on Isolated Organisms In-vivo.

\begin{tabular}{|c|c|c|c|c|}
\hline Conc. (g) & R. stolonifer & A. niger & A. flavus & P. capsici \\
\hline 20 & 95.76 & 18.81 & 8.52 & 2.71 \\
\hline 30 & 48.05 & 12.10 & 5.57 & 2.52 \\
\hline 40 & 24.38 & 5.52 & 2.81 & 2.11 \\
\hline 0 & 121.67 & 19.85 & 8.71 & 7.05 \\
\hline LSD (0.05) & 17.42 & 3.73 & 1.21 & 1.50 \\
\hline
\end{tabular}

Table 7: The Efficacy of Different Concentration of Mango Leaf Extracts on Isolated Organisms In-vitro.

\begin{tabular}{|c|c|c|c|c|}
\hline Conc. $(\mathbf{m l})$ & R. stolonifer & A. niger & A. flavus & P. capsici \\
\hline 5 & 30.90 & 11.30 & 11.50 & 15.74 \\
\hline 10 & 27.32 & 9.40 & 9.33 & 14.73 \\
\hline 15 & 23.32 & 3.31 & 6.82 & 4.05 \\
\hline 0 & 40.10 & 17.28 & 16.25 & 31.81 \\
\hline LSD (0.05) & 4.11 & 1.78 & 1.90 & 3.61 \\
\hline
\end{tabular}

Table 8: The Efficacy of Wood Ash on Isolated Organisms In-vitro.

\begin{tabular}{|c|c|c|c|c|}
\hline Conc. (g) & R. stolonifer & A. niger & A. flavus & P. capsici \\
\hline 1 & 30.07 & 8.15 & 13.71 & 13.00 \\
\hline 3 & 28.50 & 7.70 & 12.00 & 12.52 \\
\hline 5 & 16.62 & 6.70 & 9.20 & 2.20 \\
\hline 0 & 40.06 & 17.28 & 16.26 & 31.81 \\
\hline LSD (0.05) & 4.50 & 1.22 & 1.41 & 3.63 \\
\hline
\end{tabular}

Table 9: Mean Efficacy of Rice Chaff In-vivo on Isolated Organisms.

\begin{tabular}{|c|c|c|c|c|}
\hline Conc. & R. stolonifer & A. niger & A. flavus & P. capsici \\
\hline Treatment & 9.33 & 5.81 & 3.05 & 1.48 \\
\hline Control & 121.67 & 19.85 & 8.71 & 7.05 \\
\hline LSD (0.05) & 1.50 & 1.55 & 1.29 & 0.65 \\
\hline
\end{tabular}




\section{References}

1. Neel R, Vandana Md N, Ibrahim Md. A Review on Curcubita pepo. International Journal of Pharmacognosy and Phytochemical Research. 2017; 9: 1190 -1194.

2. Wolford R, Ban KE. Pumpkin and More. University of Illinois Extension. 2008; 19: 2014.

3. Facciola S. Cormucopia. As Source Book of Edible Plant. Kamping Publication California, USA. 1990; 677.

4. Agrios GN. Plant Pathology, Academic Press, New York 7. 2005.

5. Kader AA. Post-harvest Technology of Horticultural Crops. University of California, Agriculture and Natural Resources. 2002; 3311.

6. Davis RM, Gubler WD, Koike UC. Plant Pathology. University of California State wide. EPM Program. 2008; 78-80.

7. Sommer NF. Strategies for control of post-harvest disease of selected commodities. In: Post-harvest Technology of Horticultural Crops. University of California Press.1985; 83-98.

8. Hausbeck MK, Lamour KH. Phytophthora capsici on vegetable crops: research progress and management challenges. Plant Disease. 2004 88: $1292-1303$.

9. Erwin DC, Ribeiro OK. Phytophthora Diseases Worldwide. American Phytopathological Society, St. Paul, MN.1996.

10. Thomas AZ. Fusarium Diseases of Cucurbits. Department of Plant Pathology, Cornell University.1998; 733.

11. Ijato JY. Inhibitory Effects of Indigenous Plant Extracts (Zingiber officinale and Ocimum gratissimum) on Post-Harvest yam rot, in vitro. Journal of American Science. 2011; 7: 43-47.

12. Bristone B, Chimbekujwo IB, Pukuma MS. Control of Post-harvest Fungal Rot of Sweet Potatoes (Ipomea batatas) in Yola. Nigerian Journal of Botany. 2011; 24: 43-51.

13. Bonaldo SM, Schwan-Estrade KRF, Stangarlin JR, Tessmann D, Scapim CA. Fungitoxicity, Phytoalexins Elicitor Activity and Protection of Cucumber Against Collentotrichum lagenarium,by Eucalyptus citriodora Aqueous Extract. Fitopatologia Brasileira. 2004; 29: 128-134.

14. Rodrigues E, Schwan-Estrada KRF, Fiori ACG, Stangarlin JR, Cruz MES Fungitoxicity, phytoalexins Elicitor Activity and Protection of lettuce in Organic Growth Against Sclerotinia Sclerotiorum by Ginger Extract. Summa Phytopathologica. 2007; 33: 20-24.

15. Aisha M, Basiri B, Chimbekujwo IB. Effect of Different Storage Method on development of Post-Harvest Rot of Solenoslemon rotundifolius (Poir). Journal of Biology Agriculture and Healthcare. 2013; 3: 136-139.

16. Muhammed S, Suberu HA, Amusa NA, Agaji MD. The Effect of Soil Amendment with Sawdust and Rice Husks on the growth and incidence of seedling blight of Tamarrindus indica Linn caused by by Macrophomina phaseolina and Rhizoctonia solani. Moor J. Agric. Res. 2001; 2: 40-46.

17. Anjili SM, Channya FK, Chimbekujwo IB. Fungi Associated with Post-harvest Spoilage of Date Palm (Phoenix dactylifera L.) in Yola Adamawa State. International Journal of Research in Agriculture and Forestry. 2015; 2: 14-22.

18. Fawole MO, Oso BA. Laboratory Manual of Microbiology. $1^{\text {st }}$ edition Spectrum Books Ltd, Ibadan, Nigeria. 1995; 34-35.

19. Robert AS, Hoekstra, Frisvad JC, Filtenborg O. Introduction to Foodborne Fungi. Printed by Ponsen and Looyen, Wageningen. The Netherlands. 1996.

20. Chukwuka KS, Okonko IO, Adekunle AA. Microbial Ecology of Organisms Causing Pawpaw (Carica papaya L.) Fruit Decay in Oyo State, Nigeria. American-Eurasian Journal of Toxicological Sciences. 2010; 2: 43-50.
21. Nene $Y$, Thapilyal L. Poisoned food technique of fungicides in plant disease control. $3^{\text {rd }}$ Ed. Oxford and TBH Publishing Company, New Delhi. 2000.

22. Bristone B. Identification and control of fungi associated with the postharvest fungal rot of sweet potatoes (Ipomoea batatas) in Yola. Nigeria Journal of Botany. 2004; 24: 43-51.

23. Anjili SM, Channya FK, Chimbekujwo IB. Control of Fungi Isolated from Date Palm Fruit in Yola, Adamawa State. Journal of Biology, Agriculture and Healthcare. 2016; 6: 9-16.

24. Tsado EK, Aghotor P, Ebitemi G, Oyeleke SB, Gana RW. Fungi Associated with Spoilage of some Edible Vegetables in and Around Minna, Niger State, Nigeria. Global Journal of Biology, Agriculture and Health Sciences. 2013; 2: 110-113.

25. Mapanda F, Mangwayana EN, Nyamangara J, Giller KE. 'The effect of long-term irrigation using wastewater on heavy metal contents of soils under vegetables in Harare, Zimbabwe', Agricultural Ecosystem and Environment. 2005; 107:151-65.

26. Amadioha AC, Obi VI. Control of Anthracnose Disease of Cowpea by Cymbopogon citratus and Ocimum gratissimum. Acta Phytopathologica et Entomologica Hungarica. 1999; 34: 85-89.

27. Zakari BG, Chimbekujwo IB, Channya FK, Bristone B. In vitro Antifungal Activity of Selected Plant Diffusates against Post-Harvest Fruits Rot of pepper (Capsicum Spp. L.) in Yola. Global Journal of Biology, Agriculture and Health Sciences. 2015; 4: 142-148.

28. Brian CF, Gwyn AB. An Overview of Plant Defenses against Pathogens and Herbivores. An Overview of Plant Defenses against Pathogens and Herbivores. The Plant Health Instructor. 2008.

29. Babadoost M. The Fruit Rots of Pumpkin. Report on Plant Disease. University of Illinois Extension. RPD no. 950. 2012.

30. Hausbeck MK, Keinath AP, Kousik CS, Matheron ME. Managing Phytophthora disease with fungicides. Phytopathology, APS Centennial celebration in Minneapolis, MN. 2008.

31. Jamuna S, Subramaniam P, Karthika K. In vitro Antifungal Activity of Leaf and Root Exracts of the Medicinal Plant, Hypochaeris radicata $L$. International Journal of Pharmacy and Pharmceutical Sciences. 2013; 5: 758-761.

32. Marjorie MC. Plant products as antimicrobial agents. Clin. Microbiol. Rev. 1999; 12: 564-582. PubMed: https://www.ncbi.nlm.nih.gov/ pubmed/10515903

33. Jigna $P$, Sumitra $C$. In-vitro antimicrobial activities of extracts of Launaea procumbns Roxb. (Labiateae), Vitis vinifera L. (Vitaceae) and Cyperus rotundus L. (Cyperaceae). Afri. J. Biomed.Res. 2006; 9: 89-93.

34. Mark WA, Channya KF, Chimbekujwo IB, Bristone B. Control of Colletotrichum capsici of cowpea in the Savanna using ash. Global Journal of Biology, Agriculture and Health Sciences. 2015; 4:136-141.

35. Channya FK, Chimbekujwo IB. Pathogens of Post-harvest Fruits Rot of Plantain (Musa Parasidiaca L.) in South- Western Nigeria. Journal of Tropical Bioscience. 2002; 21-24.

36. Oguntade TO, AA, Adekunle. Preservation of seeds against fungi using wood-ash of some tropical forest trees in Nigeria. African Journal of Microbiology Reserve. 2010; 4: 279-288.

37. Aliyu TH, Balogun OS, Alade 0O. Assessment of the Effect of Rate and Time of Rice-Husk Powder as an Organic Amendment on Cowpea (Vigna unguiculata L. Walp) Inoculated with cowpea mottle Virus. Agriculture and Biology Journal of North America. 2011; 2: 74-79.

38. Muhammed S, Israr H, ljaz AK, Abdur R, Ibadullah J, et al. Influence of Organic Mulches on Growth and Yield Components of Pea's Cultivars. Greener Journal of Agricultural Sciences. 2013; 3: 652-657. 